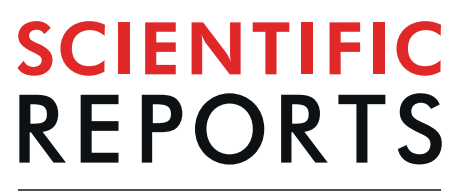

natureresearch

Check for updates

\title{
Preceding Viral Infections Do Not Imprint Long-Term Changes in Regulatory T Cell Function
}

\author{
Felix Rost ${ }^{1}$, Katharina Lambert ${ }^{1,2}$, Nikolas Rakebrandt ${ }^{1,3}$ \& Nicole Joller ${ }^{1 凶}$
}

Regulatory $T$ cells $\left(T_{\text {regs }}\right)$ maintain peripheral self-tolerance and limit immune mediated pathology. Like effector $T$ cells, $T_{\text {regs }}$ can specialize in $T_{H} 1$-dominated immune responses and co-express $T$-bet together with Foxp3. This allows for expression of CXCR3 and efficient homing to sites of $\mathrm{T}_{\mathrm{H}} 1$ responses. However, whether such functional specialization is paralleled by memory generation among $T_{\text {regs }}$ is unknown. In this study, we investigated the ability of polyclonal $T_{\text {regs }}$ to form functional memory in response to viral infection. Using adoptive transfer models to compare infection-experienced $T_{\text {regs }}$ generated upon acute Lymphocytic Choriomeningitis Virus (LCMV) WE and Vaccinia Virus (VV) infections with naive $T_{\text {regsı }}$ we observed no differences in their phenotype or their in vivo maintenance. When comparing functional properties of infection-experienced and naive $\mathrm{T}_{\text {regs }}$, we found no differences in in vitro suppressive capacity nor in their ability to limit the effector response upon homologous, systemic or local re-challenge in vivo. Our results suggest that no functional $\mathrm{T}_{\text {reg }}$ memory is generated in the context of systemic LCMV orVV infection, but we cannot rule out the possibility that the generation of $T_{\text {reg }}$ memory may be possible in other contexts.

Regulatory $\mathrm{T}$ cells $\left(\mathrm{T}_{\text {regs }}\right)$ restrain autoreactive effector $\mathrm{T}$ cells that have escaped negative selection in the thymus to maintain self-tolerance, and negatively regulate immune responses. During infections, $\mathrm{T}_{\text {reg }}$-mediated immune regulation requires tight coordination to allow for efficient pathogen clearance by effector cells while minimizing immune-mediated damage to host cells and tissues ${ }^{1}$. In the context of a primary immune response pathogen-specific CD4+ effector T cells can terminally differentiate into T helper $1\left(\mathrm{~T}_{\mathrm{H}} 1\right), \mathrm{T}_{\mathrm{H}} 2, \mathrm{~T}_{\mathrm{H}} 17$ or $\mathrm{T}_{\mathrm{FH}}$ cells ${ }^{2}$. Once a pathogenic threat has been neutralized, activated effector $\mathrm{T}$ cells undergo contraction after which only a small number of pathogen-specific memory $\mathrm{T}$ cells remain. These long-lived memory cells can, upon pathogen re-encounter, respond with an enhanced kinetic and magnitude and render secondary immune responses more effective ${ }^{3}$

Primary viral infections predominantly induce a $\mathrm{T}_{\mathrm{H}} 1$ effector differentiation program that is driven by the master transcription factor T-bet, which regulates expression of the $\mathrm{T}_{\mathrm{H}} 1$-specific chemokine receptor CXCR3 ${ }^{4}$. In parallel to effector $\mathrm{T}$ cells, a fraction of the Foxp $3+\mathrm{T}_{\text {reg }}$ population can mirror this specialization program by co-expressing T-bet and Foxp3 and up-regulating CXCR3. This process is dynamically regulated, specific and essential for the effective control of $\mathrm{T}_{\mathrm{H}} 1$ polarized immune responses ${ }^{5,6}$ and enables $\mathrm{T}_{\text {regs }}$ to accumulate in tissues of $\mathrm{T}_{\mathrm{H}} 1$ mediated inflammation ${ }^{7}$. CXCR3 $+\mathrm{T}_{\text {regs }}$ were found to be potent suppressors of $\mathrm{T}_{\mathrm{H}} 1$ cells and upregulate markers associated with suppressive function such as LAG-3 or CD85k . Several groups, including our own, have reported an induction of CXCR3 $+\mathrm{T}_{\text {regs }}$ during the acute phase of $\mathrm{T}_{\mathrm{H}} 1$ response ${ }^{5,6,8}$. However, whether, in line with memory generation in effector $T$ cells, this functional specialization also leads to long-term changes in $T_{\text {regs }}$ and the generation of $\mathrm{T}_{\text {reg }}$ memory, is still unclear.

Several important aspects separate effector from memory $\mathrm{T}$ cells. These include long-term persistence in the absence of cognate antigen and enhanced response kinetics and/or function upon homologous re-challenge ${ }^{1}$. However, applying these criteria to establish if $\mathrm{T}_{\text {reg }}$ memory can be generated is problematic. Firstly, classical memory markers of effector $\mathrm{T}$ cells such as CD44 are already expressed by a considerable fraction of $\mathrm{T}_{\text {regs }}$ under homeostatic conditions ${ }^{9}$, and indeed until today no reliable markers of memory $\mathrm{T}_{\text {regs }}$ have been identified ${ }^{1}$. However, because T-bet and CXCR3 were reported to be induced and stably expressed by $\mathrm{T}_{\text {regs }}$ during and after acute $\mathrm{T}_{\mathrm{H}} 1$ responses ${ }^{5,6}$ both may represent useful markers to identify cells with the capacity to generate memory.

${ }^{1}$ University of Zurich, Institute of Experimental Immunology, Zurich, 8057, Switzerland. ${ }^{2}$ Present address: Translational Research Program, Benaroya Research Institute, Seattle, WA, 98101, USA. ${ }^{3}$ Present address: F. Hoffmann-La Roche, Basel, 4070, Switzerland. ${ }^{凶}$ e-mail: nicole.joller@immunology.uzh.ch 
Secondly, detecting persistence of non-self-specific memory $\mathrm{T}_{\text {regs }}$ in the absence of their cognate antigen in vivo is complicated by the fact that the $\mathrm{T}_{\text {reg }}$ TCR repertoire is presumed to be largely skewed towards recognizing self-antigen ${ }^{10}$ and thus pathogen-specific $\mathrm{T}_{\text {regs }}$ may be low in number for some pathogens, or completely absent for others. This observation does, however, not preclude the existence of pathogen-specific $\mathrm{T}_{\text {regs }}$ in vivo and, indeed, several research groups have successfully identified pathogen-specific $\mathrm{T}_{\text {regs }}$ by tetramer staining in mice ${ }^{11-14}$. Consequently, murine in vivo models of acute, transient infection may allow to examine pathogen-specific memory formation by characterizing the responses and in vivo maintenance of an inflammation-experienced, polyclonal $\mathrm{T}_{\text {reg }}$ population in general and of $\mathrm{T}$-bet + or CXCR3 $+\mathrm{T}_{\text {regs }}$ in particular under physiologic conditions and in the absence of cognate antigen. In accordance with this, several research groups have used TCR-transgenic $\mathrm{T}_{\text {regs }}$ to address memory formation in models of viral infection in vivo. Adoptively transferred $\mathrm{T}_{\text {regs }}$ specific for influenza A virus (IAV) hemagglutinin (HA) expanded following an acute infection with a recombinant virus that encoded $\mathrm{HA}$, then underwent contraction and upon homologous re-challenge expanded more rapidly and significantly reduced the recall expansion of effector $\mathrm{T}_{\text {cells }}{ }^{15}$. Similar observations including $\mathrm{T}_{\text {reg }}$ expansion, contraction and accelerated re-expansion during homologous viral re-challenge were made by another group that addressed the responses of TCR-transgenic $\mathrm{T}_{\text {regs }}$ specific for the IAV nucleoprotein ${ }^{16}$. However, whether these findings can also be applied to the endogenous, polyclonal $\mathrm{T}_{\text {reg }}$ population is still unclear.

In this study, we compared the phenotypic and functional properties of polyclonal $\mathrm{T}_{\text {regs }}$ from naive and infection-experienced mice using two models of homologous viral re-challenge. We show that infection-experienced, polyclonal $\mathrm{T}_{\text {regs }}$ do not exhibit superior maintenance in the absence of an immunologic challenge and do not show marked differences in their phenotype. Furthermore, naive and infection-experienced $\mathrm{T}_{\text {regs }}$ did not differ in their suppressive capability and do not alter systemic or localized anti-viral effector $\mathrm{T}$ cell responses upon homologous systemic or tissue localized re-challenge in vivo. In summary, we did not observe $\mathrm{T}_{\text {reg }}$ memory responses within the endogenous polyclonal $\mathrm{T}_{\text {reg }}$ pool.

\section{Results}

In vitro suppressive capacity of $\mathrm{T}_{\text {regs }}$ from infection-experienced and naive mice is comparable. Expression of the transcription factor T-bet and the downstream chemokine receptor CXCR3 by $\mathrm{T}_{\text {regs }}$ in viral infections was shown to be dynamically regulated ${ }^{8}$ and essential for the control of $\mathrm{T}_{\mathrm{H}} 1$ polarized immune responses $^{5,6}$. However, despite clear evidence that the expression of transcription factors such as T-bet ${ }^{5}, \mathrm{Rbpj}^{17}$, IRF $4^{18}$, or STAT3 ${ }^{19}$ by $T_{\text {regs }}$ is required to regulate $T_{H} 1, T_{H} 2$ or $T_{H} 17$ immune responses, it is still unclear if such phenotypic polarization is also paralleled by memory formation. It was shown that an acute LCMV infection induces the expression of T-bet and CXCR3 as well as $\mathrm{T}_{\text {reg }}$ effector molecules such as LAG-3, TIM-3, and CD85k at the peak of the infection ${ }^{8}$. However, 30-60 days after primary infection with LCMV or VV the absolute $\mathrm{T}_{\text {reg }}$ numbers in infection-experienced or naive mice were comparable across lymphoid and non-lymphoid organs (Supplementary Fig. 1A,B). Similarly, we observed no differences in the MFI of T-bet and the frequency of CXCR3 $+\mathrm{T}_{\text {regs }}$ (Supplementary Fig. 1C,D), nor in the frequency of neuropilin-1- peripherally induced $\mathrm{p}_{\text {regs }}$ (Supplementary Fig. 1E,F). Still, we surmised that the infection-experienced $\mathrm{T}_{\text {reg }}$ pool may be enriched for memory $\mathrm{T}_{\text {regs }}$ of enhanced suppressive capacity that may not be marked by enhanced expression of CXCR3 and thus not be readily detectable within the total $\mathrm{T}_{\text {reg }}$ population. Additionally, even though CXCR3 $+\mathrm{T}_{\text {regs }}$ were isolated at similar frequencies from naive or infection-experienced mice (Supplementary Fig. 2A) their suppressive capacity may still be different because only $\mathrm{T}_{\text {regs }}$ from infection-experienced mice had been exposed to a potent inflammatory environment. Thus, we wanted to determine whether there might be differences in the suppressive capacity of polyclonal infection-experienced or naive $\mathrm{T}_{\text {regs. }}$ To address this question, we compared their ability to suppress $\mathrm{T}_{\mathrm{H}} 1$ effector cells in an in vitro suppression assay. To generate infection-experienced $\mathrm{T}_{\text {regs, }}$, Foxp3-GFP reporter mice were acutely infected with LCMV to induce a potent $\mathrm{T}_{\mathrm{H}} 1$ polarized immune response. $\mathrm{CD} 4+$ Foxp3-GFP $+\mathrm{T}_{\text {regs }}$ were sorted from LCMV-experienced (day 30) or naive Foxp3-GFP reporter mice and co-cultured with anti-CD3 stimulated CD4+GFP - effector T cells from acutely LCMV infected mice in an in vitro suppression assay. We observed a pronounced and similar suppression of proliferation of CD4+GFP- effector $\mathrm{T}$ cells from LCMV infected mice by both naive or LCMV-experienced $\mathrm{T}_{\text {regs }}$ (Fig. 1A,B). The quantification of the cytokine IFN- $\gamma$ in the supernatants of the suppression assays confirmed the equivalent suppressive capacity of both $\mathrm{T}_{\text {reg }}$ populations (Fig. 1C). We also observed similar suppression of proliferation of CD4+GFP- effector $\mathrm{T}$ cells isolated from naive donor mice by $\mathrm{T}_{\text {regs }}$ from naive or LCMV-experienced mice (Supplementary Fig. 2B,C). Next, we wanted to address whether LCMV-experienced $\mathrm{T}_{\text {regs }}$ might show superior LCMV-specific suppression. To this end, we tested the ability of naive and LCMV-experienced $\mathrm{T}_{\text {regs }}$ to suppress antigen-specific stimulation of LCMV gp61-specific SMARTA effector T cells in an in vitro suppression assay. We found that neither naive nor LCMV-experienced $\mathrm{T}_{\text {regs }}$ were able to suppress SMARTA cell proliferation despite the fact that both $\mathrm{T}_{\text {reg }}$ populations were functional when stimulated with anti-CD3 (Supplementary Fig. 2D). To determine whether LCMV gp66-specific $\mathrm{T}_{\text {regs }}$ are at all present in these $\mathrm{T}_{\text {reg }}$ populations, we next performed a gp66 tetramer staining. We found that splenic CD4+ Foxp3 $+\mathrm{T}_{\text {regs }}$ and Foxp3- effector T cells of naive mice indeed harbored LCMV gp66-specific cells at similar frequencies (Fig. 1D). However, while gp66-specific CD4+ effector T cells were detectable at higher numbers 30 days after acute LCMV infection, the absolute numbers of gp66-specific $\mathrm{T}_{\text {regs }}$ remained unchanged in LCMV-experienced mice, suggesting that these cells, while detectable, did not expand in vivo (Fig. 1E).

$T_{\text {regs }}$ from infection-experienced and naive mice are maintained equally well in vivo. Assessing the suppressive capacity of $\mathrm{T}_{\text {regs }}$ in an in vitro suppression assay is a useful, yet biologically constrained means to compare $\mathrm{T}_{\text {reg }}$ function. We hypothesized, that potential differences between $\mathrm{T}_{\text {regs }}$ from naive and infection-experienced mice might emerge in vivo because in vitro suppression assays do not allow to capture all possible suppressive mechanisms that can be employed by $\mathrm{T}_{\text {regs }}$ such as e.g. the impairment of effector $\mathrm{T}$ cell 
A
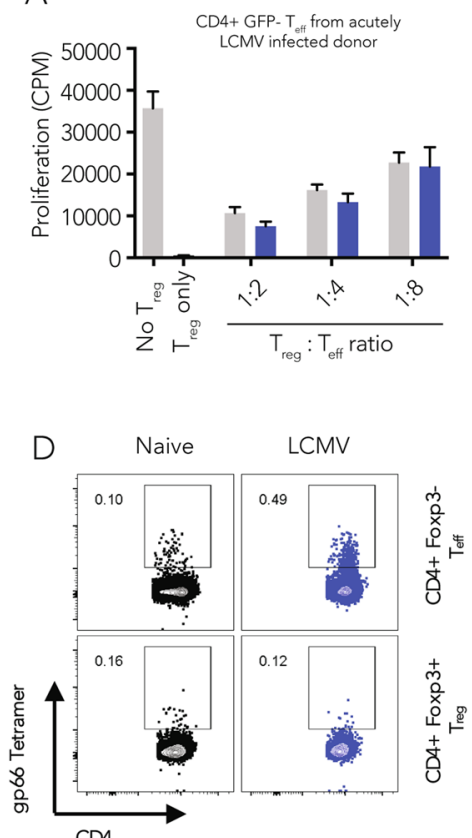

B
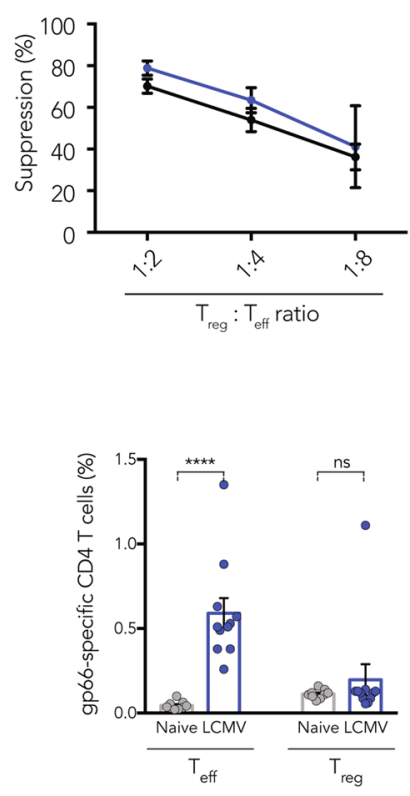

C

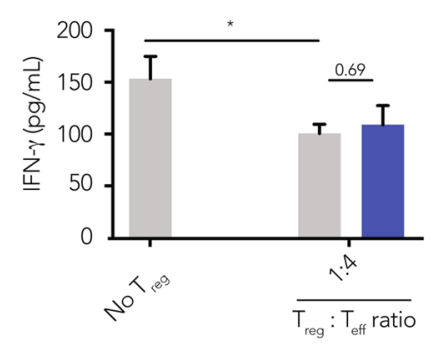

E

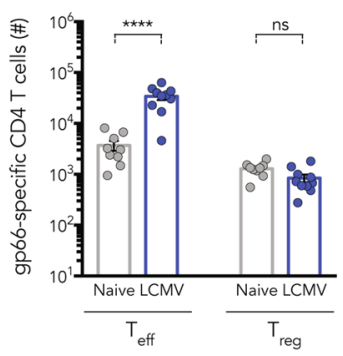

Figure 1. Infection-experienced $\mathrm{T}_{\text {regs }}$ show trend for higher in vitro suppressive capacity. $\mathrm{CD} 4+\mathrm{GFP}+\mathrm{T}_{\text {regs }}$ were sorted from naive or LCMV-experienced Foxp3-GFP reporter mice and co-cultured with CD4+GFPeffector cells isolated from acutely LCMV infected donor mice in the presence of soluble anti-CD3 $(1 \mu \mathrm{g} / \mathrm{ml})$ and irradiated splenic APCs isolated from naive mice for 2 days, then $\left[{ }^{3} \mathrm{H}\right]$ thymidine was added for $18-22 \mathrm{~h}$ and $\left[{ }^{3} \mathrm{H}\right]$ thymidine incorporation was quantified to determine proliferation. Target cell proliferation (A) and calculated $\mathrm{T}_{\text {reg }}$-mediated suppression (B) are shown. (C) The concentration of IFN- $\gamma$ in the suppression assay supernatants harvested after $48 \mathrm{~h}$ of co-culture was determined by cytometric bead assay. (Mean $\pm \mathrm{SD}$; biological replicates: no $T_{\text {regs }}$, naive $T_{\text {regs }}$, memory $T_{\text {regs }} n=6 ; 2$ independent experiments) (one way ANOVA and multiple comparisons test, $* p<0.05, * * p<0.01, * * * p<0.001)$. (D) Splenic T cells from naive or LCMV-experienced mice ( $>30$ days post infection) were stained using gp66 tetramers to detect LCMVspecific CD4+Foxp3+ $\mathrm{T}_{\text {regs }}$ or CD4+Foxp3- effector T cells. Frequencies and absolute numbers are shown. (Mean \pm SD; biological replicates: naive $n=8$, LCMV-experienced $n=9 ; 3$ independent experiments) ( $t$ Test, $* * * * p<0.0001)$.

recruitment to inflammatory sites ${ }^{20}$. To obtain a more comprehensive overview of the functionality and relevance of potential memory formation, we next studied $\mathrm{T}_{\text {regs }}$ in in vivo models of infection.

One defining feature of $\mathrm{T}$ cell memory is the stable maintenance of antigen-specific memory $\mathrm{T}$ cells long after the cognate antigen has been cleared ${ }^{1}$. We thus wondered if a polyclonal $\mathrm{T}_{\text {reg }}$ pool isolated from infection-experienced mice, and thus potentially enriched for memory $\mathrm{T}_{\text {regs }}$, would show signs of prolonged in vivo maintenance in the absence of an immune challenge. To test this, we performed adoptive co-transfers of congenically marked polyclonal CD4+GFP $+\mathrm{T}_{\text {regs }}$ isolated from naive $(\mathrm{CD} 45.1+)$ or LCMV-experienced $(\mathrm{CD} 45.2+)$ Foxp3-GFP reporter mice at a 1:1 ratio into naive CD90.1+ recipient mice and the purity of the transferred cell population was confirmed by Foxp3 staining (Fig. 2A). The recipient mice were then sacrificed 21 to 28 days after transfer to compare the phenotype and absolute numbers of the CD45.1+ or CD45.2+ recovered $\mathrm{T}_{\text {regs. }} \mathrm{T}_{\text {regs }}$ recovered from the spleen of recipient mice showed similar frequencies of cells expressing the IL-2 receptor alpha chain (CD25), the chemokine receptor CXCR3, the activation marker CD44, the co-inhibitory receptor TIGIT, and the transcription factor Ki67, which marks cells that actively undergo cell cycling (Fig. 2B). Thus, there appeared to be no selective, preferential in vivo maintenance or enrichment of CXCR3+LCMV-experienced compared to naive $\mathrm{T}_{\text {regs }}$. We also found that the 1:1 ratio of transferred naive and LCMV- experienced $\mathrm{T}_{\text {regs }}$ was maintained in spleen, pooled peripheral lymph nodes, bone marrow and lung of the recipient mice and we recovered similar absolute numbers of both populations in all organs tested (Fig. 2C). This suggested that the in vivo maintenance of naive or LCMV-experienced $\mathrm{T}_{\text {regs }}$ is similar across primary and secondary lymphoid organs as well as peripheral tissues such as the lung and there seemed to be no preferential homing of LCMV-experienced $\mathrm{T}_{\text {regs }}$ to any particular site. Overall, we did not observe any differences in the phenotype and in vivo maintenance of polyclonal $\mathrm{T}_{\text {regs }}$ isolated from naive or LCMV-experienced donor mice.

$T_{\text {reg }}$ cell phenotype and function in systemic viral re-challenges are comparable. Next, we compared the in vivo responses of naive or infection-experienced $\mathrm{T}_{\text {regs }}$ in homologous viral re-challenges and quantified their effect on the endogenous anti-viral effector $\mathrm{T}$ cell response. We found that adoptive transfer of $5 \times 10^{5}$ polyclonal $\mathrm{T}_{\text {regs }}$ is sufficient to dampen the endogenous effector $\mathrm{T}$ cell response (Supplementary Fig. 3 ) and thus used this as a basis to assess the suppressive function of naive vs. infection-experienced $\mathrm{T}_{\text {regs }}$ in vivo. To this end, 

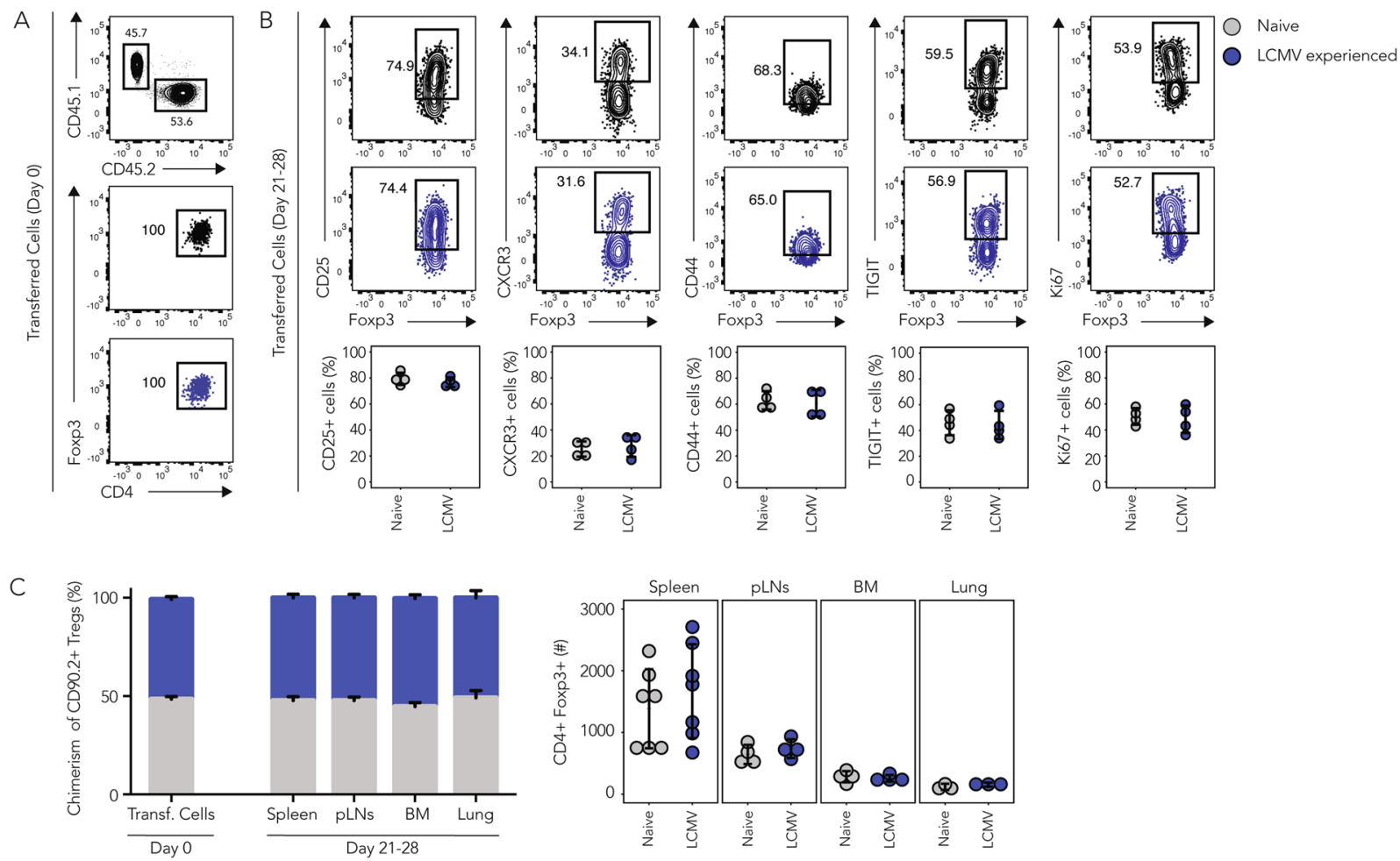

Figure 2. Infection-experienced and naïve $\mathrm{T}_{\text {regs }}$ are equally well maintained in vivo. $\mathrm{CD} 4+\mathrm{GFP}+\mathrm{T}_{\text {regs }}$ were sorted from naive (CD45.1) or LCMV-experienced (CD45.2) Foxp3-GFP reporter mice and 500'000 of each population were adoptively co-transferred i.v. into naive CD90.1+ recipient mice. Organs from $\mathrm{T}_{\text {reg }}$ recipients were harvested and analyzed by flow cytometry 21-28 days after transfer. (A) Characterization of $\mathrm{T}_{\text {regs }}$ from naive and LCMV-experienced mice before transfer. Input ratio (top) and purity (bottom) are shown in representative plots. (B) On day 21-28 post transfer, expression of CD25, CXCR3, CD44, TIGIT and Ki67 was determined in naive or LCMV-experienced CD4+Foxp3 $+\mathrm{T}_{\text {regs }}$ isolated from the spleens of recipient mice. Representative plots (top) and summary plots (bottom) are depicted. (C) Chimerism (left) and absolute numbers (right) of CD90.2 $\mathrm{T}_{\text {regs }}$ recovered from the indicated organs on day 21 to 28 post transfer. $(B, C)$ Cumulative data (Mean \pm SD; biological replicates: Spleen $n=7$, pLNs $n=4, B M n=4$, Lung $n=3 ; 4$ independent experiments) ( $\mathrm{t}$ Test, $* p<0.05, * * p<0.01$, *** $p<0.001$ ).

we isolated bulk $\mathrm{T}_{\text {regs }}$ from naive or LCMV-experienced Foxp3-GFP reporter mice $>30$ days after the primary infection and adoptively transferred $5 \times 10^{5} \mathrm{~T}_{\text {regs }}$ into separate groups of naive, congenically marked recipient mice. 1 day after the adoptive transfer, recipient mice were challenged with LCMV and 10 days later the spleens were harvested and the phenotype of the transferred $\mathrm{T}_{\text {regs }}$ and the endogenous effector $\mathrm{T}$ cell responses were compared. We already showed earlier that the phenotype of naive or LCMV-experienced $\mathrm{T}_{\text {regs }}$ was comparable at the day of transfer (Supplementary Fig. 2A). The absolute numbers of naive or LCMV-experienced $\mathrm{T}_{\text {regs }}$ recovered from the spleen of recipient mice on day 10 after systemic viral re-challenge did not differ (Fig. 3A). This indicated that $\mathrm{T}_{\text {regs }}$ isolated from LCMV-experienced mice did not show signs of more pronounced expansion or superior maintenance upon homologous LCMV re-challenge in vivo. Furthermore, we did not observe differences in the frequency of T-bet + or CXCR3 + cells among naive or LCMV-experienced $\mathrm{T}_{\text {regs }}$, indicating that the homologous re-challenge did not induce a preferential enrichment of $T_{H} 1$ suppressing $T_{\text {regs }}$ among the LCMV-experienced $T_{\text {reg }}$ population (Fig. 3B). Also, the expression of the memory and activation marker CD44, as well as the co-inhibitory receptor TIGIT did not differ. The frequency of Ki67+ cells was also similar and suggested no differences in cell cycling between $\mathrm{T}_{\text {regs }}$ isolated from naive or LCMV-experienced mice.

To determine whether $\mathrm{T}_{\text {regs }}$ from infection-experienced or naive mice differed in their ability to suppress effector T cells in vivo, we compared the endogenous effector T cell response after LCMV-specific ex vivo peptide re-stimulation. Again, we did not observe any differences in the frequencies or absolute numbers of splenic IFN- $\gamma+\mathrm{CD} 8+$ or CD4+ effector T cells in recipients of naive or LCMV-experienced $\mathrm{T}_{\text {regs }}$ (Fig. 3C). Similarly, no differences were detected in the frequencies or absolute numbers of TNF- $\alpha+$ CD8 + or CD4+ effector T cells (Supplementary Fig. 4A). Also, re-stimulation of total splenocytes using PMA/Ionomycin revealed no differences in the frequency or absolute number of IFN- $\gamma+\mathrm{CD} 8+$ or CD4+ effector T cells (Supplementary Fig. 4B).

To exclude the possibility that the potent anti-viral immune response elicited by LCMV ${ }^{21}$ could mask potentially small differences in the $\mathrm{T}_{\text {reg }}$ phenotype or their impact on an ongoing anti-viral immune response, we performed an analogous second set of experiments using Vaccinia Virus (VV) instead of LCMV. As for LCMV, the phenotype of $\mathrm{T}_{\text {regs }}$ isolated from naive or VV-experienced mice was similar (Supplementary Fig. 1B,D,F and Supplementary Fig. 2A) and we adoptively transferred these bulk populations into separate groups of congenically 
A

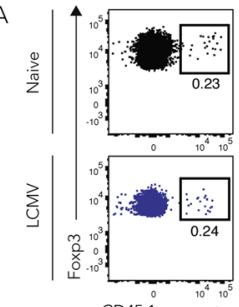

$\mathrm{CD} 45.1 \stackrel{10^{4}}{\longrightarrow}$

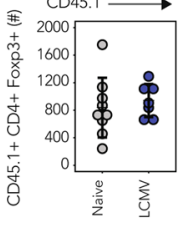

B
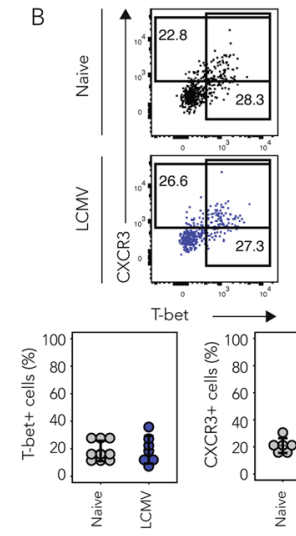
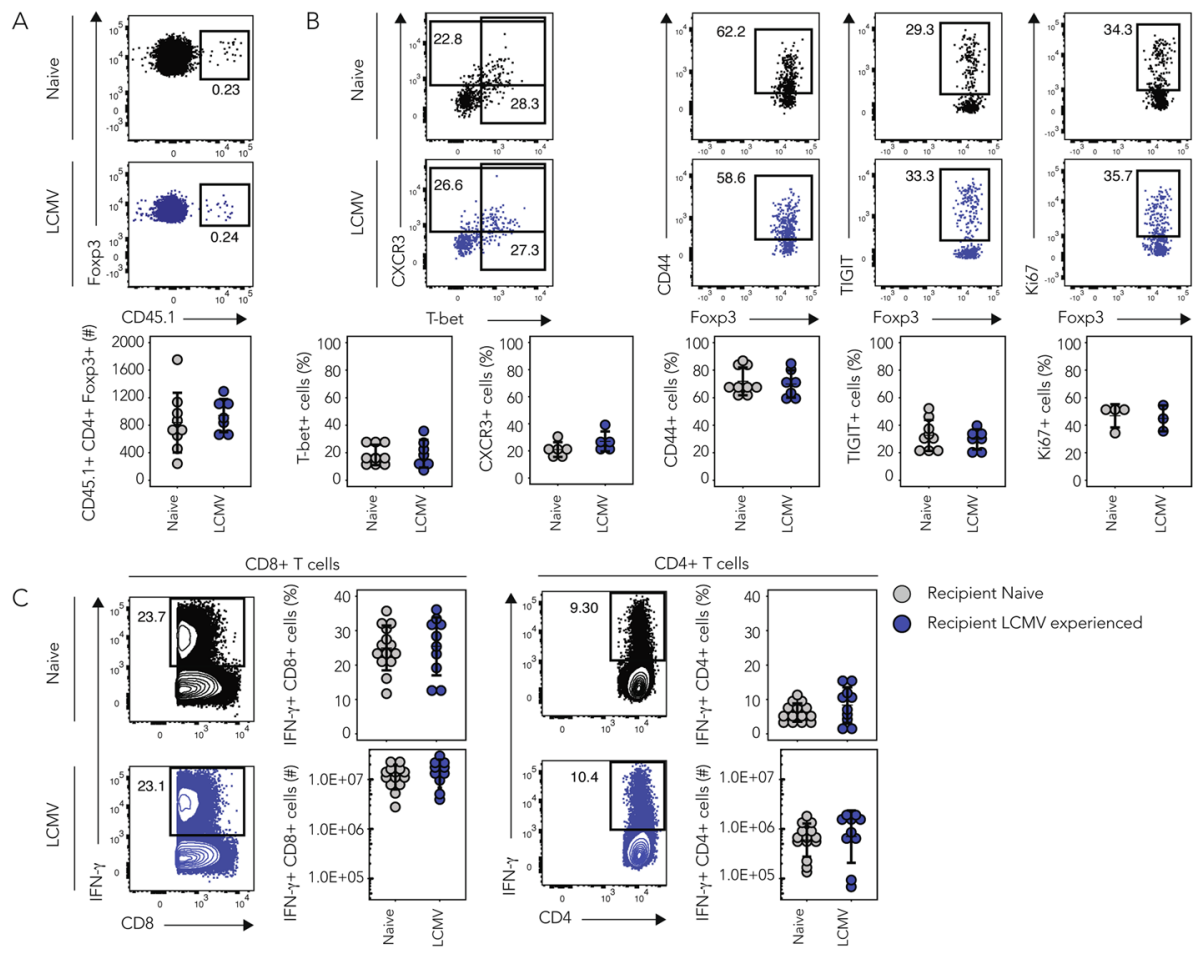

D

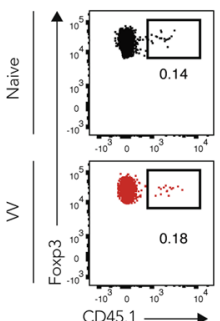

E
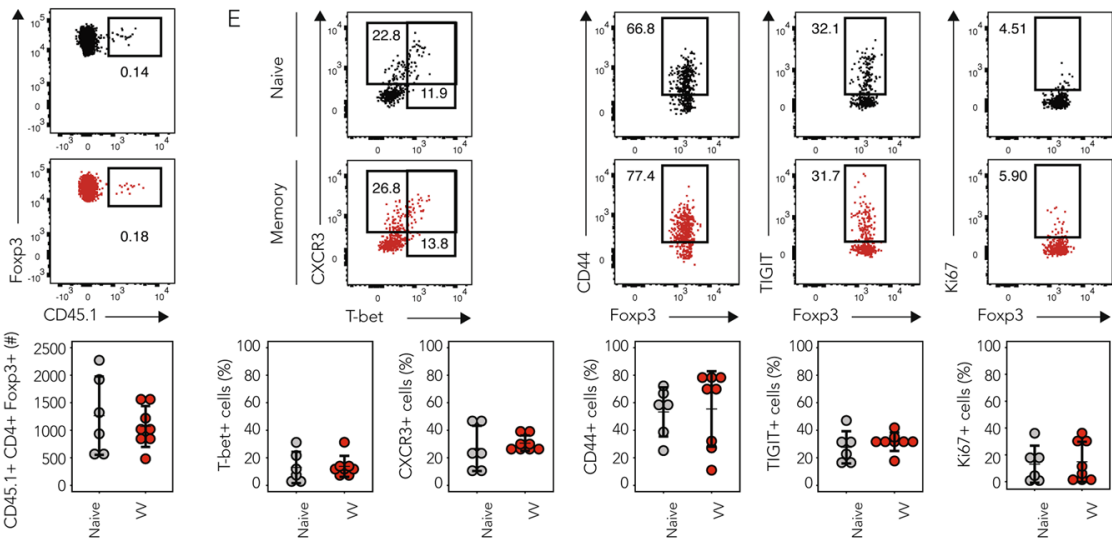

O Naive

W experienced
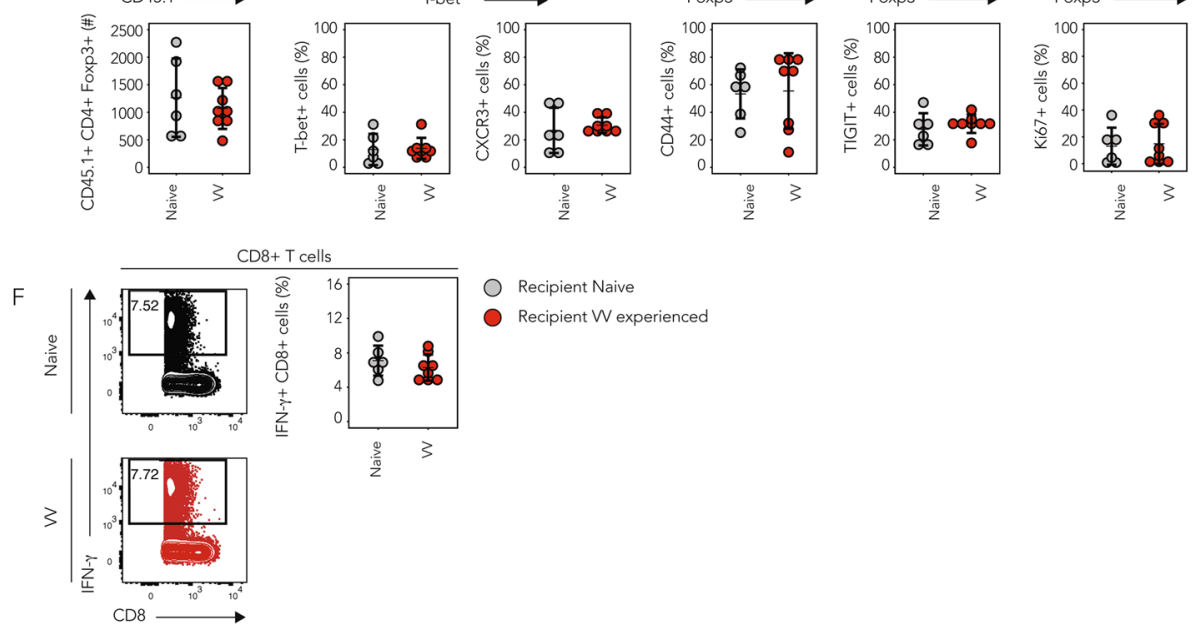

Naive

- LCMV experienced

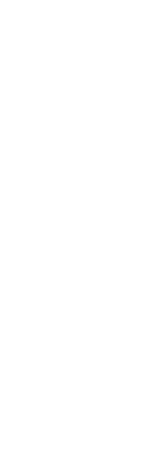


the transferred $\mathrm{T}_{\text {regs }}$ characterized in the spleen (D). Frequencies of transferred naive or VV-experienced $\mathrm{T}_{\text {regs }}$ within the total $\mathrm{T}_{\text {reg }}$ population (top) and absolute numbers of recovered, transferred $\mathrm{T}_{\text {regs }}$ (bottom). (E) Naive or $\mathrm{VV}$-experienced transferred $\mathrm{T}_{\text {regs }}$ were phenotypically characterized by flow cytometry. Representative plots (top) and cumulative data (bottom) depicting frequencies of marker positive cells among the transferred $\mathrm{T}_{\text {regs }}$. (F) Splenocytes of recipient mice were re-stimulated with VV peptide for $4 \mathrm{~h}$ followed by intracellular cytokine staining for IFN- $\gamma$. (Mean \pm SD; biological replicates: naive $n=6, V V$-experienced $n=8 ; 2$ independent experiments) (t Test, $* p<0.05, * * p<0.01, * * * p<0.001)$.

marked recipient mice and infected them with VV one day after the transfer. 7 days after the systemic viral re-challenge the spleens of the recipient mice were harvested for analysis. As for LCMV, we did not observe differences in the absolute numbers of naive or VV- experienced $\mathrm{T}_{\text {regs }}$ recovered from the spleen (Fig. 3D). Flow cytometric analysis did also not show any differences in the frequency of T-bet + or CXCR $3+, \mathrm{CD} 44+$, TIGIT + or $\mathrm{Ki} 67+$ cells among the transferred $\mathrm{T}_{\text {regs }}$ (Fig. 3E). Furthermore, no differences in the frequency of IFN- $\gamma+$ or TNF- $\alpha+$ CD8 + effector T cells were observed after VV-specific re-stimulation (Fig. 3F, Supplementary Fig. 4C) or of IFN- $\gamma+\mathrm{CD} 8+$ or CD4+ effector T cells after re-stimulation of total splenocytes using PMA/Ionomycin (Supplementary Fig. 4D).

Overall, neither LCMV- nor VV-experienced $\mathrm{T}_{\text {regs }}$ showed enhanced expression of T-bet or CXCR3, increased activation, or cell cycling. In line with this, the absolute numbers of naive or infection-experienced $\mathrm{T}_{\text {regs }}$ that we recovered from the spleen of recipient mice did not differ. We also did not observe differences in the magnitude of the endogenous anti-viral CD8+ or CD4+effector T cell response in the presence of infection-experienced compared to naive $\mathrm{T}_{\text {regs. }}$. This suggested that in our model system of adoptive $\mathrm{T}_{\text {reg }}$ transfer the presence of infection-experienced $\mathrm{T}_{\text {regs }}$ did not alter the course of the anti-viral immune response nor did the $\mathrm{T}_{\text {regs }}$ differ in their phenotype for the markers that we investigated.

$\mathbf{T}_{\text {reg }}$ cell responses in localized viral re-challenges are comparable. We found that in systemic homologous re-challenges the phenotype and the capacity of naive or infection-experienced $\mathrm{T}_{\text {regs }}$ to regulate effector $\mathrm{T}$ cell responses was comparable. Nevertheless, as virus-specific memory $\mathrm{T}_{\text {regs }}$ were shown to be able to expand in $v i v o^{15,16,22}$, and because expression of T-bet has been reported to be stable over time ${ }^{5,6}$ we hypothesized that infection-experienced $\mathrm{T}_{\text {regs }}$ might, upon viral re-challenge, show faster recruitment to the site of a localized viral infection compared to naive $\mathrm{T}_{\text {regs }}$. This is because $\mathrm{T}$-bet-dependent expression of CXCR3 has been suggested to allow $\mathrm{T}_{\text {regs }}$ to co-localize with CXCR3 $+\mathrm{T}_{\mathrm{H}} 1$ effector $\mathrm{T}$ cells at inflammatory sites ${ }^{6,7}$. We thus analyzed whether infection-experienced $\mathrm{T}_{\text {regs }}$ might show enhanced suppressive capacity in a localized re-challenge model of infection. Injection of LCMV into the footpad of mice induces a tissue localized anti-viral immune response that results in effector T cell influx and tissue swelling ${ }^{23}$. Similarly, epicutaneous VV infection in the ear results in a localized infection with CXCR3-dependent and infection site-restricted recruitment of virus-specific CD8+ T cells $^{24}$. We thus employed these two localized models of infection and tested if infection-experienced $\mathrm{T}_{\text {regs }}$ could migrate more efficiently to sites of ongoing $\mathrm{T}_{\mathrm{H}} 1$ mediated inflammation and if they could reduce the local effector response (as measured by tissue swelling) at the infected site. We also assessed the endogenous effector $\mathrm{T}$ cell responses to address the possibility of a potentiated immune regulation exerted by infection-experienced $\mathrm{T}_{\text {regs }}$

In the LCMV model, we performed subcutaneous infections in the hind footpad of mice that had received either LCMV-experienced or naive $\mathrm{T}_{\text {regs }}$ (Fig. 4A). The swelling of the infected site was measured daily and mice were sacrificed 13 days after local LCMV re-challenge. We did not observe differences in the swelling of the footpads between recipients of naive or LCMV-experienced $\mathrm{T}_{\text {regs }}$ (Fig. 4B), nor did we observe differences in the frequencies of IFN- $\gamma+$ CD8 + or CD4+ effector T cells in the footpad draining popliteal lymph node after virus-specific or unspecific re-stimulation (Fig. 4C and Supplementary Fig. 5A). In line with these results, recipients of naive or $\mathrm{VV}$-experienced $\mathrm{T}_{\text {regs }}$ did not show differences in response to epicutaneous $\mathrm{VV}$ re-challenge, neither in ear swelling (Fig. 4D,E), nor in the frequency of IFN- $\gamma$ producing CD8+ effector T cells in the ear draining cervical lymph node (Fig. 4F), nor upon stimulation with PMA/Ionomycin (Supplementary Fig. 5B). Furthermore, neither naive nor infection experienced $\mathrm{T}_{\text {regs }}$ could be detected in the footpad draining or ear draining lymph node after local LCMV or VV infection, respectively. In summary, we could not observe differences in the recruitment or suppressive function of infection experienced and naive $\mathrm{T}_{\text {regs }}$.

\section{Discussion}

In this study, we investigated the phenotypic and functional features of polyclonal, infection-experienced $\mathrm{T}_{\text {regs }}$ in vitro, and in different $\mathrm{T}_{\mathrm{H}} 1$ responses in vivo. Using adoptive (co-)transfer experiments we found that neither the maintenance nor the suppressive function of infection-experienced $\mathrm{T}_{\text {regs }}$ was altered in vivo. Homologous, systemic viral re-challenges using LCMV or VV revealed that infection-experienced $\mathrm{T}_{\text {regs }}$ did not display an altered composition, activation, nor differences in cell cycling. Furthermore, infection-experienced polyclonal $\mathrm{T}_{\text {regs }}$ were unable to significantly dampen systemic or localized effector $\mathrm{T}$ cell responses compared to $\mathrm{T}_{\text {regs }}$ isolated from naive mice. Overall these results suggest that $\mathrm{T}_{\text {regs }}$, which have experienced a viral infection do not show an altered phenotype nor function compared to naive $\mathrm{T}_{\text {regs }}$ and thus do not display characteristics of a memory response.

Addressing the possibility that $\mathrm{T}_{\text {regs }}$ generate immunological memory is uniquely challenging and conflicting evidence for and against it has been reported. Several studies employed TCR transgenic $\mathrm{T}_{\text {regs }}$ and presented compelling evidence that pathogen-specific $\mathrm{T}_{\text {regs }}$ can generate memory cells. In an Influenza A virus (IAV) infection model, virus-specific $\mathrm{T}_{\text {regs }}$ underwent pronounced proliferation and contraction phases and yielded a small population of virus-specific $\mathrm{T}_{\text {regs }}$ that persisted long-term and, upon antigen-specific re-challenge, were recruited more effectively to the lung, expanded more rapidly and potently suppressed effector $\mathrm{T}$ cell expansion and cytokine production $^{16}$. Very similar experiments were performed by another group that also reported enhanced production 
A
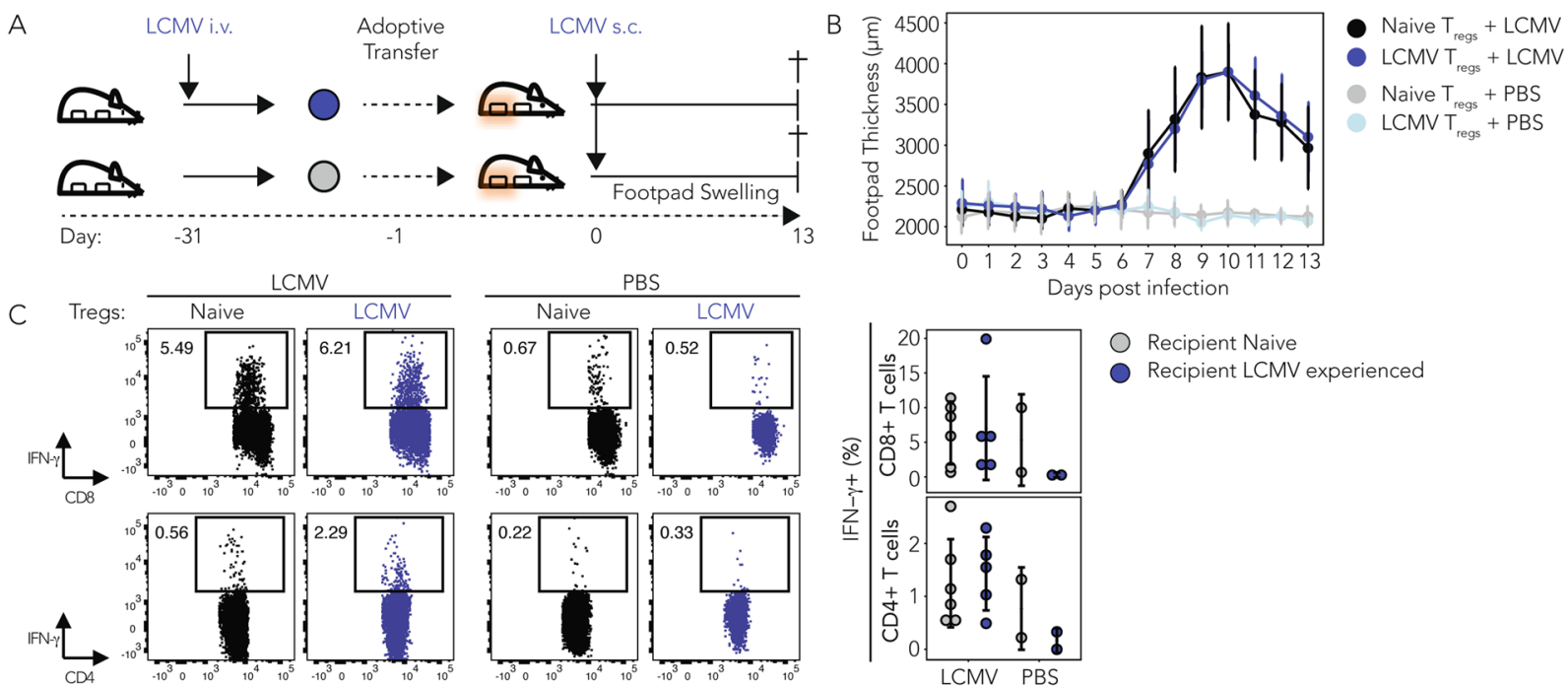

$\mathrm{D}$

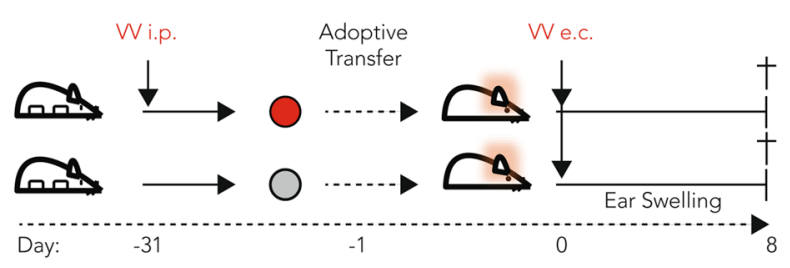

$$
\text { E }
$$
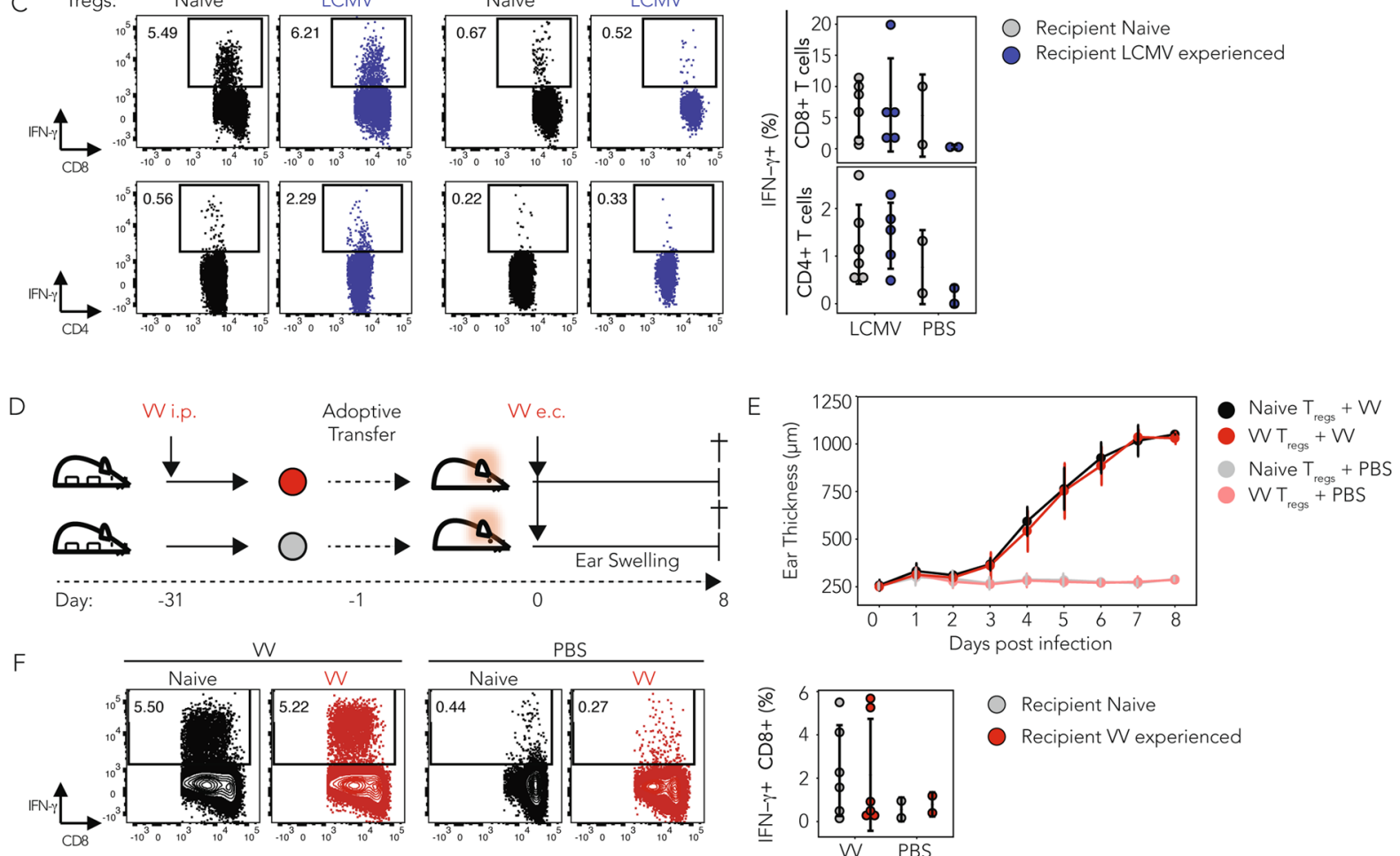

Recipient Naive

Recipient LCMV experienced

Days post infection

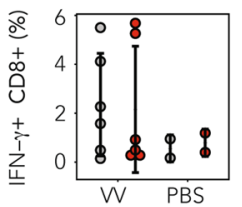

Recipient Naive

Recipient $W$ experienced

Figure 4. Adoptive transfer of infection experienced $\mathrm{T}_{\text {regs }}$ does not alter tissue swelling and effector $\mathrm{T}$ cell responses in localized, homologous viral challenges. CD4 $+\mathrm{GFP}+\mathrm{T}_{\text {regs }}$ were sorted from naive, $\mathrm{LCMV}$ experienced (A-D) or VV-experienced (E-I) CD45.2+ Foxp3-GFP reporter mice 30 days after the primary infection and 500'000 of each population were adoptively transferred into separate groups of CD45.1+ recipient mice. Recipients of naive, $\mathrm{LCMV}$ - or VV-experienced $\mathrm{T}_{\text {regs }}$ were infected subcutaneously into the hind footpad with LCMV (A-D), or epicutaneously into the ears with VV (E-I) and the swelling of the infected site was monitored daily for 13 or 8 days, respectively, with a spring loaded caliper. On the final day of the experiment mice were sacrificed and $T$ cell responses in the site draining popliteal lymph node (A-D), or cervical lymph node (E-I) characterized by FACS. (A) Schematic outline of the homologous LCMV challenge experiment. (B) Thickness of the footpads of recipients of naive or LCMV-experienced $T_{\text {regs }}$ infected with LCMV in the right hind footpad or mock infected with PBS on the contralateral side. (C) Cells from the footpad draining popliteal lymph node of recipient mice of the PBS treated side were pooled and from the infected side treated individually and re-stimulated with LCMV peptides (LCMV gp61 and gp33, $4 \mathrm{~h}$ ) followed by intracellular cytokine staining for IFN- $\gamma$. Representative plots (left) and summary graphs (right) are shown. (Mean $\pm \mathrm{SD}$; biological replicates: naive $n=6$, LCMV-experienced $n=5 ; 2$ independent experiments) (D) Schematic outline of the experimental setup to elicit homologous, localized immune challenges using VV in the ear. (E) Thickness of the ears of recipients of naive or VV-experienced $\mathrm{T}_{\text {regs }}$ that were either infected with VV epicutaneously or mock injected with PBS. (F) Cells from the ear draining cervical lymph node of recipient mice of the PBS treated side were pooled and from the infected side treated individually and re-stimulated with VV peptide $(4 \mathrm{~h})$ followed by intracellular cytokine staining for IFN- $\gamma$. Representative plots (left) and summary graphs (right) are shown. (Mean $\pm S D$; biological replicates: naive $n=6$, VV-experienced $n=6 ; 2$ independent experiments) $(\mathrm{t}$ Test $* p<0.05, * * p<0.01, * * * p<0.001)$.

of IL-10 by influenza virus-specific $\mathrm{T}_{\text {regs }}$ upon antigen-specific re-challenge ${ }^{15}$. In our study, we went beyond the limitations set by models that use TCR transgenic cells and performed adoptive transfers of polyclonal $\mathrm{T}_{\text {regs }}$ from naive or infection-experienced donor mice. Interestingly, we found no evidence of $\mathrm{T}_{\text {reg }}$ memory generation or more potent regulation of effector $\mathrm{T}$ cell responses.

Aside from the potentially enhanced functionality of memory $\mathrm{T}_{\text {regs }}$, other researchers have addressed their ability to migrate to peripheral sites and have shown that $\mathrm{T}_{\text {regs }}$ can form tissue resident memory cells ${ }^{22}$. A set of studies investigated responses of TCR transgenic $\mathrm{T}_{\text {regs }}$ in a model of inducible antigen expression in keratinocytes ${ }^{25}$ and 
found robust activation, proliferation and migration of antigen specific $\mathrm{T}_{\text {regs }}$ to the inflamed skin, reported persistence of a tissue resident, antigen-specific $\mathrm{T}_{\text {reg }}$ population in the absence of antigen expression and an accelerated response kinetic and disease amelioration upon local antigen re-expression ${ }^{22}$. The fact that in our systemic and local viral re-challenges we could not observe enhanced responses by infectionexperienced $\mathrm{T}_{\text {regs }}$ may be due to the fact that systemic viral infections, unlike tissue localized infections, may not be suited to generate $\mathrm{T}_{\text {reg }}$ memory. It is possible that memory $\mathrm{T}_{\text {regs }}$ are primarily generated in peripheral tissues and persist as tissue resident memory cells, in which case we would not be able to detect them in our experimental models. Nevertheless, based on the reported sustained expression of T-bet ${ }^{5,6}$ and pronounced re-expansion of TCR transgenic memory $\mathrm{T}_{\text {regs }}$ in vivo ${ }^{15,16,22}$ one could suspect an enhanced capacity for homing of memory $\mathrm{T}_{\text {regs }}$ to sites of local $\mathrm{T}_{\mathrm{H}} 1$ mediated inflammation. However, we did not find evidence for enhanced $\mathrm{T}_{\text {reg }}$ homing in local re-challenges. In addition, we were unable to recover any infection-experienced $\mathrm{T}_{\text {regs }}$ from the lymph nodes that drained the site of infection. While our experimental system allows for the analysis of a polyclonal $\mathrm{T}_{\text {reg }}$ response, we could not observe any expansion of $\mathrm{T}_{\text {regs }}$ specific for the immunodominant LCMV effector T helper epitope gp66 in vivo. This is in contrast to previous reports, where HA-specific $\mathrm{T}_{\text {regs }}$ were found to expand during antigen-specific primary and secondary challenge in vivo ${ }^{15}$. However, these observations were made in a TCR transgenic model system, where TCR transgenic $\mathrm{T}_{\text {regs }}$ receive very strong TCR stimulation. It is possible that the LCMV-specific $\mathrm{T}_{\text {regs }}$ we detected in naive mice receive weaker TCR signals in vivo, possibly because they represent self-specific $\mathrm{T}_{\text {regs }}$ with weak cross-reactivity for $\mathrm{LCMV}^{26}$. $\mathrm{T}_{\text {reg }}$-mediated immune regulation has been implicated in playing a role in various viral infections such as Friend Virus $^{27}$, Cytomegalovirus ${ }^{28}$, hepatitis $\mathrm{C}$ virus ${ }^{29}$, or influenza virus infections ${ }^{30}$. Interestingly, influenza virus-specific $\mathrm{T}_{\text {regs }}$ have been found to potently regulate anti-viral effector $\mathrm{T}$ cells responses in influenza infection in vivo and show enhanced suppression upon re-challenge ${ }^{16}$. However, it remains to be elucidated whether virus-specific $T_{\text {regs }}$ are also generated against other viruses. Our results suggest that LCMV-specific $\mathrm{T}_{\text {regs }}$ do not undergo expansion upon LCMV infection in vivo, possibly due to low affinity for LCMV antigens, which may have precluded memory generation. Indeed, despite clear evidence for the immunoregulatory functions of $T_{\text {regs }}, T_{\text {reg }}$ memory generation is absent in infections with, for instance, Friend Virus ${ }^{27}, \mathrm{MCMV}^{28}$, or $\mathrm{HSV}^{31}$ for which pathogen-specific $\mathrm{T}_{\text {regs }}$ have not been described so far. Thus, despite earlier reports of murine $\mathrm{T}_{\text {regs }}$ specific for various pathogens including LCMV $^{11-14}$ it still remains to be established if such cells do get activated in a viral infection and can generate functional memory. Similarly, several studies also presented evidence that argued against $\mathrm{T}_{\text {reg }}$ memory. One recent study reported that activation-induced changes in gene expression by polyclonal $\mathrm{T}_{\text {regs }}$ in a self-resolving $\mathrm{T}_{\mathrm{H}} 1$ polarized autoimmune disease were either fully or significantly reversed within 60 days of onset and resolution of the disease $^{32}$. This suggested that no functional $\mathrm{T}_{\text {reg }}$ memory was formed in a systemic $\mathrm{T}_{\mathrm{H}} 1$ polarized immune response and our data would suggest a similar conclusion. However, another study by the same group employed an intricate T-bet dual reporter system and showed that polyclonal $\mathrm{T}_{\text {regs }}$ that had expressed T-bet at the peak of a primary immune response directed against Listeria monocytogenes expanded more robustly than $\mathrm{T}_{\text {regs }}$ that de novo upregulated T-bet in a secondary, homologous re-challenge with the same pathogen ${ }^{6}$. This observation suggested that infection-experienced T-bet $+\mathrm{T}_{\text {regs }}$ are maintained long-term and retain a capacity for enhanced proliferation upon homologous re-challenge. Our data does, however, not confirm these findings as we did not observe increased absolute numbers, nor frequencies of T-bet + , CXCR3 + or Ki67 + cells among infection-experienced $\mathrm{T}_{\text {regs }}$ during homeostasis in donor animals nor during homologous systemic or localized re-challenge. As such, our study would argue against LCMV or VV pathogen-specific $\mathrm{T}_{\text {reg }}$ memory but it will be important to confirm this finding in other models that allow for the analysis of polyclonal, non-TCR transgenic $\mathrm{T}_{\text {reg }}$ populations.

\section{Methods}

Mice, pathogens, and infections. C57BL/6 (B6) mice were purchased from Janvier Laboratories and Foxp3-GFP.KI reporter ${ }^{33}$ and SMARTA ${ }^{34}$ mice have been described previously. All mice were housed and bred in SPF or OHB facilities at LASC Zurich, Switzerland. All experiments were reviewed and approved by the cantonal veterinary office of Zurich and were performed in accordance with Swiss legislation.

Lymphocytic choriomeningitis virus (LCMV) WE was propagated on L929 fibroblast cells, Vaccinia Virus (VV) on BSC40 cells. Sex- and age-matched mice, 6-12 weeks of age were infected i.v. with $200 \mathrm{ffu}$ LCMV, or i.p. with $2 \times 10^{6} \mathrm{ffu} \mathrm{VV}$. For footpad infections $50 \mu \mathrm{L}$ of PBS containing $500 \mathrm{ffu}$ of LCMV were injected s.c. into the right hind footpad ${ }^{23}$. Epicutaneous ear infections were modified from a previous report ${ }^{24}$ and performed by piercing the ear five times with a bifurcated needle that was dipped into VV stock $\left(7.65 \times 10^{8} \mathrm{ffu} / \mathrm{mL}\right)$ in between punches. The contralateral footpads or ears served as a control and were mock infected in an identical manner using sterile PBS. Swelling of the infected site was monitored daily with a spring-loaded caliper.

Isolation of leukocytes. Harvested spleens or lymph nodes were dissociated by carefully pushing them through a fine metal mesh or $70 \mu \mathrm{m}$ cell strainer, respectively, followed by red blood cell lysis using ACK buffer $\left(155 \mathrm{mM} \mathrm{NH}_{4} \mathrm{Cl}, 1 \mathrm{mM} \mathrm{KHCO}_{3}, 0.1 \mathrm{mM} \mathrm{NA}_{2}\right.$ EDTA in $\mathrm{ddH}_{2} \mathrm{O}, \mathrm{pH}$ 7.2-7.4) for spleen samples, prior to staining for flow cytometry. Bone marrow was flushed out from the femur and tibia-fibula. For isolation of lung cells, mice were perfused with sterile PBS, lungs resected and digested in RPMI medium containing DNase I $(200 \mu \mathrm{g} / \mathrm{ml}$, VWR) and Collagenase I ( $2.4 \mathrm{mg} / \mathrm{ml}$, Gibco), and dissociated using a gentleMACS (Miltenyi) according to the manufacturer's protocol. Leukocytes were purified over a 30\% Percoll (GE Healthcare) gradient and then stained for flow cytometry.

Flow cytometry. Single cell suspensions from the indicated organs were surface stained with fluorophore-conjugated antibodies for $20 \mathrm{~min}$, followed by fixation/permeabilization for $45 \mathrm{~min}$ using the Foxp3 Staining Buffer Set (eBioscience) for transcription factor staining or $10 \mathrm{~min}$ using BD Fixation/Permeabilization Solution kit (BD Bioscience) for intracellular cytokine staining, followed by intracellular staining for $40 \mathrm{~min}$ at room temperature. For gp66 tetramer staining, cells were pre-incubated with APC-conjugated tetramer for $20 \mathrm{~min}$ 
before surface staining for additional markers. For intracellular cytokine staining, isolated bulk splenocytes were re-stimulated using phorbol 12-myristate 13 -acetate (PMA, $50 \mathrm{ng} / \mathrm{mL})$ and Ionomycin $(1 \mu \mathrm{g} / \mathrm{ml}), \alpha C D 3(2 \mu \mathrm{g} / \mathrm{ml}$, BioXcell), the immunodominant LCMV peptides gp61 and gp33 $(1 \mathrm{mg} / \mathrm{ml}$; gp61: GLKGPDIYKGVYQFKSVEFD; gp33-41: KAVYNFATM) or the immuno-dominant VV CD8+ T cell epitope (10 mM, TSYKFESV, GenScript) for $4 \mathrm{~h}$ at $37^{\circ} \mathrm{C}$ in the presence of Brefeldin A $(5 \mu \mathrm{g} / \mathrm{mL}$, BioLegend). Fluorophore-conjugated antibodies against murine CD4 (RM4-5 or GK1.5), CD8 (53-6.7), Foxp3 (FJK-16s), T-bet (4B10), CXCR3 (CXCR3-173), CD44 (IM7), CD85k (H1.1), TIGIT (1G9), CD25 (PC61), IFN- $\gamma$ (XMG1.2), TNF- $\alpha$ (MP6-XT22) or Ki-67 (16A8) were purchased from BioLegend, eBioscience, or R\&D Systems. The LIVE/DEAD Fixable Near-IR Dead Cell Stain Kit (Invitrogen) was used to exclude dead cells. Counting beads (CountBright, Invitrogen) were added before flow cytometric acquisition to determine absolute cell numbers. Data were acquired on a BD LSRFortessa or BD FACSCanto II cytometer (BD Biosciences). Data were analyzed using Flowjo Software (Flowjo, LLC) and where necessary target populations were concatenated to simplify analysis.

Cell sorting by FACS. Total CD4+ T cells from virus-infected or naive control Foxp3-GFP.KI mice were isolated from bulk splenocytes and peripheral lymph nodes (inguinal, brachial, axillary, cervical) using anti-CD4 positive or negative selection beads (BioLegend), followed by FACS sorting. $\mathrm{T}_{\text {regs }}$ were FACS sorted as CD4 + GFP + cells from Foxp3-GFP reporter mice. Cell sorting was performed on a FACSAria III (BD Biosciences).

Adoptive cell transfers. $5 \times 10^{5}$ sorted $\mathrm{CD} 4+\mathrm{GFP}+\mathrm{T}_{\text {regs }}$ from infection-experienced (day $>30$ ) or naive Foxp3-GFP reporter mice suspended in $200 \mu \mathrm{l}$ PBS were adoptively transferred by i.v. injection into congenically marked naive recipient mice. The in vivo maintenance of the transferred $\mathrm{T}_{\text {reg }}$ cells was assessed 21-28 days post transfer in the indicated organs. For systemic and localized homologous challenges the $\mathrm{T}_{\text {reg }}$ recipient mice were infected with LCMV or VV one day after the adoptive transfer.

$\mathbf{T}_{\text {reg }}$ in vitro suppression assays. Suppression assays were performed as described before ${ }^{8}$. Briefly, cells were cultured in DMEM medium supplemented with $10 \%$ heat-inactivated FCS, $\beta$-mercaptoethanol $(50 \mathrm{mM})$, sodium pyruvate ( $1 \mathrm{mM}$, Gibco), non-essential amino acids (Gibco), MEM vitamins (Gibco), penicillin (50 U/ $\mathrm{mL}, \mathrm{Gibco})$, streptomycin $\left(50 \mu \mathrm{g} / \mathrm{mL}\right.$, Gibco), and Glutamine $(2 \mathrm{mM}$, Gibco $) . \mathrm{T}_{\mathrm{H}} 1$ effector cells were isolated by FACS from spleen and lymph nodes of day 10-14 LCMV-WE infected Foxp3-GFP reporter mice as CD4+GFPcells. CD4+GFP - effector cells $\left(4 \times 10^{4}\right.$ cells/well $)$ and $\mathrm{CD} 4+\mathrm{GFP}+\mathrm{T}_{\text {reg }}$ cells were co-cultured in triplicate in the presence of soluble anti-CD3 $(1 \mu \mathrm{g} / \mathrm{ml}$, BioXcell $)$ and irradiated splenic APCs $\left(2 \times 10^{5} /\right.$ well $)$ to provide co-stimulation at $37^{\circ} \mathrm{C}$ and $5 \% \mathrm{CO} 2$. After $48 \mathrm{~h}$ cells were pulsed with $1 \mu \mathrm{Ci}\left[{ }^{3} \mathrm{H}\right]$ thymidine (PerkinElmer) for an additional $18-22 \mathrm{~h}$, then harvested and $\left[{ }^{3} \mathrm{H}\right]$ thymidine incorporation was assessed to analyze $\mathrm{T}$ cell proliferation. Percent suppression $=([$ mean value of C.P.M. of wells with CD4+Foxp3 - cells alone - C.P.M. of well with the indicated ratio of effector $\mathrm{T}: \mathrm{T}_{\text {reg }}$ cells]/[mean C.P.M. of wells with CD4+Foxp3- effectors alone])*100. Cytokine secretion was determined in supernatants harvested after $48 \mathrm{~h}$ of co-culture using the LEGENDplex Assay according to the manufacturer's instructions (BioLegend).

Statistical analysis. Statistical significance between two individual groups was determined using two-sided $\mathrm{t}$ Test, for more than two groups one-way ANOVA was used. Assessment was performed using Prism7 or R software. Statistical significance values are indicated as follows: $\mathrm{p}<0.05(*), \mathrm{p}<0.01(* *)$ and $\mathrm{p}<0.001(* * *)$.

Ethical approval and informed consent. All animal experiments were reviewed and approved by the cantonal veterinary office of Zurich and were performed in accordance with Swiss legislation as detailed in the methods section.

\section{Data availability}

All relevant data of the article and its supplementary files are available from the corresponding author upon request.

Received: 9 December 2019; Accepted: 15 April 2020;

Published online: 20 May 2020

\section{References}

1. Rosenblum, M. D., Way, S. S. \& Abbas, A. K. Regulatory T cell memory. Nat. Rev. Immunol. 16, 90-101 (2016).

2. Zhu, J., Yamane, H. \& Paul, W. E. Differentiation of Effector CD4 T Cell Populations. Annu. Rev. Immunol. 28, 445-489 (2010).

3. Gasper, D. J., Tejera, M. M. \& Suresh, M. CD4 T-Cell Memory Generation and Maintenance. Crit. Rev. Immunol. 34, 121-146 (2014).

4. Cretney, E., Kallies, A. \& Nutt, S. L. Differentiation and function of Foxp3+ effector regulatory T cells. Trends Immunol. 34, 74-80 (2013).

5. Koch, M. A. et al. T-bet controls regulatory T cell homeostasis and function during type-1 inflammation. Nat. Immunol. 10, 595-602 (2009).

6. Levine, A. G. et al. Stability and function of regulatory T cells expressing the transcription factor T-bet. Nature, https://doi. org/10.1038/nature22360 (2017).

7. Hasegawa, H. et al. Therapeutic effect of CXCR3-expressing regulatory T cells on liver, lung and intestinal damages in a murine acute GVHD model. Gene Ther. 15, 171-182 (2008).

8. Littringer, K. et al. Common Features of Regulatory T Cell Specialization During Th1 Responses. Front. Immunol. 9 (2018).

9. Firan, M., Dhillon, S., Estess, P. \& Siegelman, M. H. Suppressor activity and potency among regulatory T cells is discriminated by functionally active CD44. Blood 107, 619-627 (2006).

10. Weissler, K. A. \& Caton, A. J. The role of T-cell receptor recognition of peptide:MHC complexes in the formation and activity of Foxp3+ regulatory T cells. Immunol. Rev. 259, 11-22 (2014). 
11. Johanns, T. M., Ertelt, J. M., Rowe, J. H. \& Way, S. S. Regulatory T Cell Suppressive Potency Dictates the Balance between Bacterial Proliferation and Clearance during Persistent Salmonella Infection. PLoS Pathog. 6 (2010).

12. Shafiani, S. et al. Pathogen-Specific Treg Cells Expand Early during Mycobacterium tuberculosis Infection but Are Later Eliminated in Response to Interleukin-12. Immunity 38, 1261-1270 (2013).

13. Zhao, J. et al. IFN- $\gamma$ - and IL-10-expressing virus epitope-specific Foxp3 + T reg cells in the central nervous system during encephalomyelitis. J. Exp. Med. 208, 1571-1577 (2011).

14. Srivastava, S., Koch, M. A., Pepper, M. \& Campbell, D. J. Type I interferons directly inhibit regulatory T cells to allow optimal antiviral T cell responses during acute LCMV infection. J. Exp. Med. 211, 961-974 (2014).

15. Sanchez, A. M., Zhu, J., Huang, X. \& Yang, Y. The Development and Function of Memory Regulatory T Cells After Acute Viral Infections. J. Immunol. Baltim. Md. 1950 189, 2805-2814 (2012).

16. Brincks, E. L. et al. Antigen-Specific Memory Regulatory CD4+Foxp3+ T Cells Control Memory Responses to Influenza Virus Infection. J. Immunol. 190, 3438-3446 (2013).

17. Delacher, M. et al. Rbpj expression in regulatory T cells is critical for restraining T H 2 responses. Nat. Commun. 10, 1621 (2019).

18. Zheng, Y. et al. Regulatory T-cell suppressor program co-opts transcription factor IRF4 to control TH2 responses. Nature 458, 351-356 (2009).

19. Chaudhry, A. et al. CD4+ Regulatory T Cells Control TH17 Responses in a Stat3-Dependent Manner. Science 326, 986-991 (2009).

20. Vignali, D. A. A., Collison, L. W. \& Workman, C. J. How regulatory T cells work. Nat. Rev. Immunol. 8, 523-532 (2008).

21. Cousens, L. P. et al. Two Roads Diverged: Interferon $\alpha / \beta$ - and Interleukin 12-mediated Pathways in Promoting T Cell Interferon $\gamma$ Responses during Viral Infection. J. Exp. Med. 189, 1315-1328 (1999).

22. Gratz, I. K. et al. Cutting Edge: Self-Antigen Controls the Balance between Effector and Regulatory T Cells in Peripheral Tissues. J. Immunol. 192, 1351-1355 (2014).

23. Zinkernagel, R. M. H-2 restriction of virus-specific T-cell-mediated effector functions in vivo. II. Adoptive transfer of delayed-type hypersensitivity to murine lymphocytic choriomeningits virus is restriced by the $\mathrm{K}$ and $\mathrm{D}$ region of H-2. J. Exp. Med. 144, 776-787 (1976).

24. Hickman, H. D. et al. CXCR3 Chemokine Receptor Enables Local CD8+ T Cell Migration for the Destruction of Virus-Infected Cells. Immunity 42, 524-537 (2015).

25. Rosenblum, M. D. et al. Response to self antigen imprints regulatory memory in tissues. Nature 480, 538-542 (2011).

26. Larkin, J., Picca, C. C. \& Caton, A. J. Activation of CD4+ CD25+ regulatory T cell suppressor function by analogs of the selecting peptide. Eur. J. Immunol. 37, 139-146 (2007).

27. Robertson, S. J., Messer, R. J., Carmody, A. B. \& Hasenkrug, K. J. In vitro suppression of CD8+ T cell function by Friend virusinduced regulatory T cells. J. Immunol. Baltim. Md 1950 176, 3342-3349 (2006).

28. Almanan, M. et al. Tissue-specific control of latent CMV reactivation by regulatory T cells. PLOS Pathog. 13, e1006507 (2017).

29. Cabrera, R. et al. An immunomodulatory role for $\mathrm{CD} 4(+) \mathrm{CD} 25(+)$ regulatory $\mathrm{T}$ lymphocytes in hepatitis $\mathrm{C}$ virus infection. Hepatol. Baltim. Md 40, 1062-1071 (2004).

30. Su, L. F., Alcazar, D., del, Stelekati, E., Wherry, E. J. \& Davis, M. M. Antigen exposure shapes the ratio between antigen-specific Tregs and conventional T cells in human peripheral blood. Proc. Natl. Acad. Sci. 113, E6192-E6198 (2016).

31. Lund, J. M., Hsing, L., Pham, T. T. \& Rudensky, A. Y. Coordination of Early Protective Immunity to Viral Infection by Regulatory T Cells. Science 320, 1220-1224 (2008).

32. van der Veeken, J. et al. Memory of Inflammation in Regulatory T Cells. Cell 166, 977-990 (2016).

33. Bettelli, E. et al. Reciprocal developmental pathways for the generation of pathogenic effector T H 17 and regulatory T cells. Nature 441, 235-238 (2006).

34. Oxenius, A., Bachmann, M. F., Zinkernagel, R. M. \& Hengartner, H. Virus-specific major MHC class II-restricted TCR-transgenic mice: effects on humoral and cellular immune responses after viral infection. Eur. J. Immunol. 28, 390-400 (1998).

\section{Acknowledgements}

The authors would like to thank the NIH Tetramer Core Facility for the gp66 tetramer, Maries van den Broek for providing Vaccinia Virus, Nina Henle for technical assistance, and members of the Joller group for discussions. This work was supported by the Swiss National Science Foundation (PP00P3_150663 and PP00P3_181037 to N.J.) and the European Research Council (677200 Immune Regulation to N.J.).

\section{Author contributions}

N.J. conceived the experiments, F.R. conducted the experiments with support from K.L. and N.R., F.R. analyzed the results and wrote the manuscript, N.J. acquired the funding, supervised the research and edited the manuscript. All authors reviewed the manuscript.

\section{Competing interests}

The authors declare no competing interests.

\section{Additional information}

Supplementary information is available for this paper at https://doi.org/10.1038/s41598-020-65212-9.

Correspondence and requests for materials should be addressed to N.J.

Reprints and permissions information is available at www.nature.com/reprints.

Publisher's note Springer Nature remains neutral with regard to jurisdictional claims in published maps and institutional affiliations.

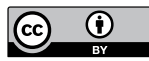

Open Access This article is licensed under a Creative Commons Attribution 4.0 International License, which permits use, sharing, adaptation, distribution and reproduction in any medium or format, as long as you give appropriate credit to the original author(s) and the source, provide a link to the Creative Commons license, and indicate if changes were made. The images or other third party material in this article are included in the article's Creative Commons license, unless indicated otherwise in a credit line to the material. If material is not included in the article's Creative Commons license and your intended use is not permitted by statutory regulation or exceeds the permitted use, you will need to obtain permission directly from the copyright holder. To view a copy of this license, visit http://creativecommons.org/licenses/by/4.0/.

(C) The Author(s) 2020 